\title{
ANALISIS STRATEGI PEMBELAJARAN BAHASA INDONESIA PADA SISWA MADRASAH TSANAWIYAH NEGERI 2 SAMBAS
}

\author{
Budiyono \\ FTIK IAIN Pontianak \\ budi2014.yono@gmail.com
}

Received: 5th of October 2020, Accepted: $19^{\text {th }}$ of November 2020, Published: $24^{\text {th }}$ of December 2020

\begin{abstract}
Abstrak
Mengingat pentingnya keterampilan berbahasa Indonesia, sehingga diakomodir di dalam kurikulum pendidikan yang menempatkan Bahasa Indonesia sebagai mata pelajaran yang wajib diberikan. Namun, Siswa kelas 7 MTsN 2 Sambas terbiasa menggunakan Bahasa Melayu Sambas saat pembelajaran berlangsung. Penelitian ini menggambarkan proses pembelajaran Bahasa Indonesia di Sekolah tersebut dengan menggunakan metode deskriptif. Analisis dilakukan dengan mengumpulkan, mendisplay dan mereduksi data untuk kemudian ditarik kesimpulan. Keterampilan siswa dalam membaca tulisan berbahasa Indonesia terbilang baik, namun keterampilan menulis dan berbicara masih kurang memuaskan. Strategi Guru untuk membiasakan siswa berbahasa Indonesia terutama di dalam kelas dengan memberikan reward (penghargaan) bagi siswa yang berbahasa Indonesia dan punishment (Hukuman) bagi yang melanggar berupa aktivitas bercerita menggunakan Bahasa Indonesia dengan baik dan benar. Secara bertahap menunjukan perubahan positif terhadap keterampilan berbicara menggunakan Bahasa Indonesia di kelas.
\end{abstract}

kata kunci : strategi pembelajaran, bahasa indonesia, bahasa melayu sambas

\begin{abstract}
The importance of Indonesian language skills to be accommodated in the education curriculum who consider Indonesian as subjects that must be given. However, 7th grade students of MTsN 2 Sambas used to use Sambas Malay while learning. This study describes the process of learning Indonesian at the school using descriptive methods. Analysis by collecting, displaying and reducing data and drawing conclusions. Students' skills in reading Indonesian writing are good, but not writing and speaking is still not satisfying. Teacher strategies to familiarize students with Indonesian, especially in the classroom by offering a reward for students who speak Indonesian and Punishment for violator in the form of storytelling activities by Indonesian students properly and correctly. Gradually shows positive change of Indonesian language speaking skills when learning.
\end{abstract}

keywords : learning problems, indonesian language, sambas malay language

\section{PENDAHULUAN}

Bahasa Indonesia merupakan alat komunikasi resmi bagi warga Negara Kesatuan Republik Indonesia. Setiap orang diharapkan mampu menggunakan Bahasa Indonesia saat berkomunikasi kepada sesama warga. Menurut Ade Hikmat dan Nani S (2013:15-16) mengutip hasil seminar Politik Bahasa Nasional tahun 1975 di Jakarta menghasilkan beberapa rumusan tentang kedudukan Bahasa Indonesia antara lain: 1) Bahasa Nasional yang berfungsi sebagai; Lambang kebanggaan nasional, identitas nasional, alat pemersatu dan alat penghubung antara budaya dan antar daerah. 
2) Bahasa Negara yang berfungsi sebagai; Bahasa resmi kenegaraan, Bahasa pengantar resmi lembaga Pendidikan, Bahasa resmi perhubungan Nasional untuk kepentingan perencanaan dan pelaksanaan pembangunan serta pemerintah, Bahasa resmi pengembangan kebudayaan dan IPTEK. Bangsa Indonesia merupakan Negara kepulauan yang memiliki aneka ragam budaya dan bahasa. Berdasarkan data yang dirilis oleh Kementerian Pendidikan dan kebudayaan (2019:2-9) mengidentifikasi Bahasa Daerah di Indonesia berjumlah 668 menurut dialektologi dan 750 menurut sosiolinguistik. Wilayah Kalimantan Barat sendiri memiliki bahasa daerah relatif sedikit dibanding daerah lain yakni berjumlah 9 Bahasa Daerah dan khusus Kabupaten Sambas tercatat memiliki 2 Bahasa Daerah.

Bahasa merupakan bentuk komunikasi lisan, tulisan maupun simbol sebagai sistem isyarat yang berarti alat untuk menyampaikan informasi kepada orang lain (Lidwina dan Izhar, 2015). Bahasa Indonesia adalah salah satu alat penyampai informasi atau alat komunikais dimaksud. Beberapa masyarakat di wilayah tertentu kesulitan menggunakan Bahasa Indonesia, karena kesehariannya menggunakan Bahasa Daerah untuk berkomunikasi dan bersosialisasi. Bahkan, dapat dijumpai warga yang sama sekali tidak mengerti berbahasa Indonesia. Seorang peneliti yang ingin mewawancarai warga di suatu wilayah tertentu bahkan harus menggunakan jasa penerjemah Bahasa Daerah setempat untuk mendapatkan informasi yang diinginkan. Begitu pula seorang guru saat ditugaskan untuk mengajar di wilayah tertentu yang menggunakan Bahasa Daerah terbilang asing baginya, diperlukan penyesuaian terlebih dahulu agar dapat menghadirkan pembelajaran yang komunikatif. Mustahil melaksanakan pembelajaran jika antara Guru dan Siswa tidak menggunakan bahasa yang sama.

Seorang Guru harus mampu menggunakan bahasa yang dapat dimengerti oleh siswa, maka pemahaman Guru tentang kemampuan berbahasa Siswa diperlukan agar tidak terjadi perbedaan persepsi saat pembelajaran berlangsung. Pembelajaran tidak selalu berjalan mulus, hambatan komunikasi tak pelak menjadi masalah tersendiri khususnya penggunaan bahasa yang berbeda antara Guru dan Siswa. Penggunaan bahasa sebagai alat komunikasi kadang memunculkan dimensi persoalan tersendiri, meskipun bahasa yang digunakan sama tetapi karena perbedaan budaya turut mempengaruhi makna dari sebuah bahasa. Sebelum melaksanakan pembelajaran, apalagi jika bagi seorang guru suatu wilayah terbilang baru, memerlukan pengenalan tentang bahasa dan budaya di wilayah setempat agar saat melaksanakan pembelajaran dapat berjalan dengan baik dan menumbuhkan kreatifitas siswa (Arya dan Kadek, 2016:1-7). 
Sebagaimana diungkapkan pada paragraf pertama bahwa tidak semua warga Negara Indonesia termasuk pendidik memiliki kemampuan yang baik menggunakan bahasa Indonesia sebagai bahasa lisan maupun tulisan, bahkan yang terbiasa berbahasa Indonesia termasuk tulisan yang peneliti tulis dalam penelitian ini bisa jadi masih ditemukan kekeliruan jika mengacu pada penggunaan tata bahasa yang baik dan benar. Berdasarkan Uji Kemahiran Berbahasa Indonesia pada Guru tahun 2016-2018 yang memperoleh predikat Madya (memiliki kemampuan memadai namun masih mengalami kendala terkait keprofesian yang kompleks) sebesar 49\%, sedangkan predikat unggul, sangat unggul dan istimewa hanya berjumlah 23,91\% (unggul 19,46\%, sangat unggul 4,43\%, dan Istimewa $0,03 \%$ ) dan untuk 3 predikat terakhir yang disebutkan mengalami peningkatan setiap tahunnya (Anisya, 2019:39). Hasil ini menunjukkan responden 19.176 yang terdiri dari Guru Bahasa Indonesia dan Guru mata pelajaran umum rentang tahun 2016-2018 di seluruh Indonesia relatif kurang menunjukan keterampilan yang baik. Maka, asumsi bahwa siswa dan masyarakat umum lainnya bisa jadi lebih rendah keterampilan berbahasa Indonesia tidaklah berlebihan, meskipun perlu dilakukan penelitian untuk memastikan hipotesis tersebut.

Berdasarkan Permendiknas Nomor 22 Tahun 2006 tentang Standar Isi Pembelajaran Bahasa Indonesia, diberikannya pembelajaran Bahasa Indonesia sebagai alat komunikasi di tengah kemajemukan bangsa ini, menjadi instrumen perekat semua warga serta membangun kesadaran atas apresiasi kesastraan Bahasa Indonesia. Pembelajaran Bahasa Indonesia memiliki tujuan antara lain : 1) komunikasi lisan maupun tulisan dapat dilakukan secara efektif dan efisien sesuai etika yang berlaku, 2) Bangga dan menghargai Bahasa Indonesia sebagai pemersatu bangsa, 3) memahami, menggunakan secara tepat dan kreatif sesuai tujuan, 4) sebagai sarana meningkatkan kematangan intelektual, sosial dan emosional, 5) sarana meningkatkan kemampuan berbahasa, memanfaatkan dan menikmati karya sastra untuk meningkatkan wawasan, memperhalus budi pekerti. 6) menumbuhkan penghargaan dan kebanggaan terhadap bahasa Indonesia sebagai khazanah kebudayaan dan intelektual Indonesia.

Pembelajaran merupakan kombinasi yang meliputi manusia, materi, fasilitas, perlengkapan dan prosedur yang saling mempengaruhi untuk mencapai tujuan pembelajaran (Oemar Hamalik, 2014:57). Pembelajaran berupa aktivitas yang melibatkan Guru, siswa dan instrumen pendukung lainnya melalui perencanaan yang tersusun secara sistematis. Aktivitas pembelajaran tidak terbatas di ruang kelas semata, tetapi kegiatan organisasi maupun interaksi antar berbagai komponen terkait juga dapat memiliki nilai pembelajaran. Rumusan tersebut juga berlaku dalam kegiatan 
Pembelajaran mata pelajaran Bahasa Indonesia yang direncanakan untuk mengembangkan keterampilan dan menumbuhkan sikap positif berbahasa meliputi keterampilan menyimak, membaca, berbicara dan menulis. Maka, penguasaan keterampilan berbahasa Indonesia hanya dapat diraih melalui latihan terus menerus dan sistematis dengan berlatih serta membiasakan diri (Asul, 2009:7). Guru harus terlibat secara aktif memberikan bimbingan latihan baik di dalam maupun di luar kelas, senantiasa mengajak siswa berkomunikasi dengan menggunakan bahasa Indonesia. Tugas guru relatif berat untuk melatih siswa berbahasa Indonesia, karena sebagian besar siswa menggunakan Bahasa Indonesia sebagai bahasa kedua sedangkan Bahasa Daerah lebih dominan menjadi bahasa pertama di lingkungan sosial siswa.

Upaya meningkatkan keterampilan berbahasa Indonesia tidak berarti mengenyampingkan arti penting Bahasa Daerah. Melestarikan Bahasa Daerah merupakan salah satu misi Pendidikan di Indonesia yang diatur dalam Undang-undang Dasar 1945 Pasal 32 Ayat 2 dan Undang-undang Nomor 20 Tahun 2003 Tentang Sistem Pendidikan Nasional. Salah satu bentuknya yakni melaksankan pembelajaran berbasis muatan lokal, aturan tersebut mempertegas komitmen pelestarian Bahasa Daerah disamping kebudayaan masyarakat Indonesia lainnya. Namun, dalam konteks pembelajaran keterampilan berbahasa Indonesia, penggunaan bahasa daerah memiliki pengaruh negatif terhadap hasil belajar Bahasa Indonesia, hal ini dibuktikan dengan hasil belajar Bahasa Indonesia terbilang rendah khususnya bagi Siswa Sekolah Dasar (Astuti Rahman, 2016:7879). Bahasa Daerah cenderung lebih dominan penggunaannya sebagai alat komunikasi siswa, penyebabnya adalah lingkungan, kebiasaan, bahasa Ibu dan kesadaran penutur sendiri (Tarigan dan Sulistiyaningsih: 1998). Problem sintaksis cenderung terjadi pada frasa, klausa dan kalimat. Kesalahan tersebut bukan berarti penutur khususnya siswa tidak memahami konteksnya tetapi disebabkan oleh faktor-faktor yang telah diungkapkan sebelumnya sehingga redaksi maupun tutur kalimat belum diungkapkan dengan baik dan benar.

Berdasarkan pengakuan salah seorang Guru yang mengajar mata pelajaran Bahasa Indonesia mengalami kendala komunikasi terhadap siswa saat melaksanakan pembelajaran bahasa Indonesia di Madrasah Tsanawiyah Negeri 2 (MTsN 2) Kabupaten Sambas. Mayoritas siswa sejatinya relatif memahami Bahasa Indonesia yang digunakan Guru, tetapi alat komunikasi yang sering digunakan siswa saat berinteraksi terhadap Guru di Kelas yakni Bahasa Melayu Sambas. Hal ini menjadi problem tersendiri bagi Guru karena pemahaman Bahasa Daerah setempat yang masih sangat minim. Memahami Bahasa Melayu Sambas relatif mudah bagi sebagian besar masyarakat 
Indonesia khususnya masyarakat Kalimantan Barat, karena beberapa kosa kata tidak berbeda dari Bahasa Indonesia dan yang menjadi pembeda hanya logatnya semata. Mata pelajaran Bahasa Indonesia merupakan upaya untuk memberikan pengetahuan dan keterampilan berbahasa Indonesia, maka dalam proses pembelajarannya pun diharapkan dapat melatih keterampilan berbahasa Indonesia yang baik dan benar. Berdasarkan permasalahan tersebut peneliti ingin menggali informasi lebih mendalam terkait pelaksanaan pembelajaran pada mata pelajaran Bahasa Indonesia dengan kecenderungan penggunaan Bahasa Daerah oleh siswa selama berlangsungnya proses pembelajaran.

\section{METODE}

Penelitian ini menggunakan metode deskriptif, yakni berusaha menggambarkan dan menginterpretasikan objek apa adanya (Sudaryono, 2018:82). Dalam hal ini peneliti menggambarkan proses pembelajaran Bahasa Indonesia di kelas 7 Madrasah Tsanawiyah Negeri (MTsN 2) Sambas untuk kemudian melakukan telaah atas segenap peristiwa yang berlangsung selama pembelajaran. Fakta-fakta berupa penilaian sikap siswa dan prosedur pembelajaran oleh guru digambarkan dan diinterpretasikan dalam penelitian ini. Analisis data dilakukan dengan terlebih dahulu melakukan pengumpulan data lapangan, membuat display data, melakukan reduksi data hasil catatan lapangan, wawancara dan analisis dokumen serta penarikan kesimpulan (Emzir, 2018:129-135). Kemudian didukung dengan teori-teori yang memiliki relevansi terhadap temuan penelitian.

\section{HASIL DAN PEMBAHASAN}

\section{Problem Pembelajaran Bahasa Indonesia}

Kabupaten Sambas termasuk wilayah pesisir paling ujung di Provinsi Kalimantan Barat. Bahasa yang digunakan adalah Bahasa Melayu Sambas sebagai alat komunikasi sehari-hari masyarakat tersebut. Daerah lainnya yang juga menggunakan bahasa Melayu Sambas adalah Kota Singkawang dan Kabupaten Bengkayang (Wahyu D, 2016:256). Secara historis kedua wilayah tersebut sebelumnya merupakan bagian dari Kabupaten Sambas, mulai terbentuk menjadi daerah otonom setelah dilakukan pemekaran. Pengaruh Bahasa Melayu Sambas terasa sampai ke dalam ruang Kelas saat pelaksanaan pembelajaran, salah satu bentuk dukungan terhadap pelestarian Bahasa Daerah dapat diimplementasikan sebagai bahasa pengantar pembelajaran sebagaimana telah diterapkan di beberapa sekolah di Indonesia (Heni, 2017:83-91). Hal ini tampaknya bukanlah sesuatu yang patut dipermasalahkan, namun menjadi masalah saat menggunakan Bahasa Daerah 
dalam pembelajaran Bahasa Indonesia. Sebagian besar siswa kelas 7 di Madrasah Tsanawiyah Negeri (MTsN 2) Sambas, bahkan hampir seluruhnya menggunakan bahasa melayu Sambas saat berkomunikasi di dalam kelas termasuk pada mata pelajaran Bahasa Indonesia. Hanya sebagian kecil yang berusaha menggunakan Bahasa Indonesia selama di dalam Kelas meskipun dengan keterampilan terbatas.

Bahasa Melayu Sambas yang digunakan siswa di dalam kelas dapat diidentifikasi dari percakapan selama pembelajaran, diantaranya sebagai berikut :

"Bu, daan ngerti masih Bu materi Itok" (Bu, masih belum mengerti materi ini).

"Bu, biak ingar" (Bu, teman-teman berisik).

Pernyataan ini bermakna konfirmatif, ketika merasa belum dapat memahami materi pembelajaran yang telah disampaikan oleh Guru, Siswa meminta Guru untuk menjelaskan kembali materi dimaksud. Ungkapan siswa kepada Guru terjadi secara spontanitas saat penjelasan materi sedang berlangsung maupun saat guru meminta tanggapan dari siswa terhadap materi pembelajaran yang telah disampaikan. Sedangkan, kalimat kedua berupa inisiatif siswa menyampaikan pengaduan kepada guru terkait perilaku teman-teman yang membuat kegaduhan di kelas sehingga merasa bahwa pembelajarannya terganggu. Percakapan berbahasa Indonesia sejatinya lebih diharapkan khususunya pada mata pelajaran Bahasa Indonesia, nyatanya siswa terbiasa menggunakan Bahasa Melayu sambas daripada bahasa Indonesia yang kemudian mempertegas posisi Bahasa Indonesia sebagai bahasa kedua bagi Siswa kelas 7 di MTsN 2 Sambas. Kondisi tersebut juga terjadi pada sebagian besar masyarakat Indonesia yang menggunakan bahasa daerah sebagai bahasa pertama (B1) dan bahasa Indonesia sebagai bahasa kedua (B2). (Gio, 2018: 137).

Kebiasaan menggunakan Bahasa Melayu Sambas tidak memberikan pengaruh negatif terhadap hasil belajar siswa kelas 7 MTsn 2 Sambas pada mata pelajaran Bahasa Indonesia, tetapi belum dapat diasumsikan memberikan dampak positif. Hasil evaluasi menunjukkan bahwa, ratarata berada di atas nilai 75 berdasarkan Kriteria Ketuntasan Minimal (KKM) Mata Pelajaran Bahasa Indonesia. Hasil belajar tersebut belum menggambar seluruh aspek keterampilan berbahasa Indonesia, aspek yang dinilai baik hanya pada aspek keterampilan membaca. Membaca tulisan berbahasa Indonesia relatif dapat dikuasai dengan baik karena kemampuan membaca (membunyikan tulisan) rata-rata siswa Sekolah Menengah Pertama (SMP/MTs) sejatinya sudah baik, tetapi kemampuan memahami konteks bacaan pelajar di Indonesia berada pada angka 6,06\% 
dengan kategori baik sedangkan 47,11\% cukup dan 46,83 memiliki kemampuan kurang (Ananda: 2019). Memahami konteks percakapan siswa dari Bahasa Melayu Sambas ke dalam Bahasa Indonesia bagi Guru tidaklah sulit, karena secara historis Bahasa Indonesia berasal dari Bahasa Melayu, meskipun beberapa kosakata sangat berbeda tetapi substansinya relatif mampu dipahami oleh Guru. Sehingga, saat siswa menghadapi problem penggunaan Bahasa Indonesia pada penggunaan kosakata maupun kalimat tertentu, Guru dapat memberikan solusi secara tepat. Sebagai warga yang berasal bukan dari wilayah Kabupaten Sambas, kesulitan memahami Bahasa Daerah setempat masih dialami. Problem tersebut diantisipasi oleh Guru dengan mengkonfirmasi kembali kepada siswa terkait kosakata atau kalimat tertentu yang masih belum dipahami maknanya dengan baik.

Mengamati pola komunikasi yang dibangun khususnya percakapan antar siswa maupun antara guru dengan siswa di Sekolah MTsN 2 Sambas, menunjukkan sebuah realitas bahwa Bahasa Indonesia belum menjadi bahasa pemersatu sebagaimana fungsinya. Contohnya, saat siswa dan guru terlibat dalam sebuah percakapan, seorang Guru yang merupakan warga baru dan alat komunikasi yang digunakan sehari-hari yakni Bahasa Melayu Pontianak, maka saat siswa berinteraksi dengan guru yang relatif belum fasih berbahasa Melayu Sambas, para siswa justeru memilih menggunakan Bahasa Melayu Pontianak agar Guru dapat memahami substansi percakapan yang sedang terjalin. Kemampuan siswa berbicara menggunakan bahasa melayu Pontianak di sekolah tersebut sejatinya juga terbilang kurang memadai tetapi jauh lebih baik dibanding berbahasa Indonesia. Upaya mengembangkan Bahasa Indonesia menjadikannya sebagai alat komunikasi sehari-hari tampaknya merupakan pekerjaan berat bagi Guru, karena jika seseorang menggunakan Bahasa Indonesia dalam percakapan sehari-hari, pada beberapa kasus tidak mendapatkan respon sebagaimana mestinya dari lawan bicara.

Pengguna Bahasa Indonesia dianggap berlebihan bahkan dianggap mencari perhatian, bagi sebagian besar masyarakat penggunaan Bahasa Indonesia saat menjalin komunikasi tidaklah tepat karena cenderung formal sehingga menunjukkan kesan kaku dan kurang bersahabat. Bahasa Indonesia diasumsikan hanya dapat digunakan dalam kegiatan resmi kenegaraan atau lembaga resmi di tingkat daerah, bahkan penggunaan Bahasa Daerah juga ditemukan dalam forum resmi Pemerintah Daerah. Hal ini terjadi pada sebagian besar wilayah di Kalimantan Barat, secara informal telah menjadi konsensus yang berkembang di masyarakat. Beberapa ungkapan yang 
mengemuka sebagai respon terhadap seorang teman atau lawan bicara menggunakan Bahasa Indonesia (bahasa formal) dalam percakapan informal diantaranya ;

Bahasa Melayu Sambas : "krewak lalu ngomong giye” (sombong sekali berbicara seperti itu). Bahasa melayu Pontianak : "cam ye-ye gaye ngmongnye, biase jak be” (sombong sekali berbicara seperti itu, sebaiknya berbicara yang biasa saja), atau yang relatif lebih frontal "sadarlah tembuni kau di mane? ngomong kayak gitu”' (Sebaiknya menyadari diri, di mana kamu dilahirkan? Tidak perlu berbicara seperti itu).

Ungkapan sinis di atas juga diucapkan jika teman atau masyarakat setempat sebagai lawan bicara menggunakan bahasa betawi (Jakarta) dalam percakapan. Pengetahuan masyarakat dan para pelajar tentang Bahasa Jakarta diperoleh melalui saluran televisi maupun teknologi informasi lainnya, dianggap merepresentasikan bahasa kaum perkotaan khususnya Ibu Kota. Maka, bahasa tersebut dianggap kurang tepat digunakan dalam percakapan terhadap masyarakat di Kalimantan Barat. Pernyataan dimaksud tidak ditemukan selama penelitian di MTsN 2 Sambas, peneliti hanya menggambarkan salah satu hambatan dalam upaya membudayakan berbahasa Indonesia yang dapat dijumpai di beberapa daerah di Kalimantan Barat.

\section{Strategi Pembelajaran Bahasa Indonesia}

Pembelajaran Bahasa Indonesia diatur dalam kurikulum yang ditetapkan oleh Negara melalui Kementerian Pendidikan dan Kebudayaan. Seluruh Lembaga Pendidikan di Indonesia baik Negeri maupun swasta mengikuti ketentuan kurikulum yang sama, kalaupun terdapat perbedaan yakni pada metode pembelajaran dan perangkat teknis lainnya untuk mendukung tercapainya tujuan pembelajaran dimaksud. Standar keterampilan berbahasa Indonesia yang telah ditetapkan dapat tercapai melibatkan peran guru sebagai instrumen utama pembelajaran (Muh. Zein, 2016:284). Guru harus memiliki kompetensi yang memadai agar mampu memberikan peningkatan keterampilan siswa, kompetensi dimaksud tidak hanya pada aspek pengetahuan namun pemahaman tentang karakteristik siswa dan kompetensi sosial khususnya budaya yang berkembang di wilayah tempat guru melaksanakan pembelajaran. Sebagai seorang Guru mata pelajaran Bahasa Indonesia yang baru pertama kali mengajar di Kabupaten sambas, memerlukan upaya penyesuaian agar dapat melaksanakan pembelajaran dengan baik. Pada pertemuan pertama, guru harus menghadapi kenyataan bahwa bahasa komunikasi siswa di MTsN 2 Sambas memiliki perbedaan dengan bahasa yang biasa digunakan oleh Guru, hal ini menimbulkan perasaan canggung sebelum akhirnya dapat menyesuaikan diri selama kurang lebih 3 bulan. Dalam jangka 
waktu tersebut secara umum dapat menguasai situasi pembelajaran meskipun belum mampu menguasai semua budaya masyarakat khususnya karakteristik peserta didik.

Lembaga Pendidikan Madarasah Tsanawiyah Negeri (MTsN 2) Sambas termasuk sekolah yang banyak diminati oleh masyarakat di Kabupaten Sambas. Setiap pendaftar diwajibkan menjalani tahapan seleksi berupa tes tertentu yang telah ditetapkan berdasakan kebijakan kelembagaan. Sebagaimana siswa pada umumnya yang terdiri dari anak usia 12-14 Tahun memiliki karakteristik berbeda pada masing-masing individu dan secara umum senang mengeksplorasi, ingin dikagumi serta ingin mendapatkan penghargaan atas usaha yang dilakukan (Samiudin, 2017:1). Sejak pertemuan pertama, suasana menyenangkan telah berhasil terbangun di kelas, namun kalimat sapaan dari siswa terdengar asing baik secara makna maupun logat bicara. Beberapa kata sulit dipahami oleh Guru, persoalan berikutnya semakin rumit ketika harus memulai pembelajaran menggunakaan Bahasa Indonesia dan mata pelajaran yang diampu juga Bahasa Indonesia. Pembelajaran Bahasa Indonesia akan menemukan relevansinya jika alat komunikasi yang dibangun menggunakan Bahasa Indonesia, sehingga secara alamiah lebih mudah mencapai tujuan pembelajaran yang telah direncanakan. Kebiasaan menggunakan Bahasa Daerah memberikan pengaruh negatif terhadap pembelajaran bahasa Indonesia terutama pada aspek menulis dan berbicara, sebagian besar siswa masih mengalami kesulitan menulis maupun berbicara menggunakan bahasa Indonesia. Tetapi, sebagaimana telah diungkapkan sebelumnya bahwa keterampilan membaca tulisan berbahasa Indonesia tidak mengalami hambatan, kemampuan siswa relatif baik saat diminta untuk membacakan sebuah redaksi berbahasa Indonesia.

Mengajak siswa untuk senantiasa berbicara menggunakan Bahasa Indonesia di kelas khususnya pada saat jam mata pelajaran menjadi salah satu strategi Guru meningkatkan kompetensi berbahasa Indonesia. Pemberian penghargaan kepada siswa yang menggunakan bahasa Indonesia dengan baik berupa pujian dan motivasi memberikan semangat untuk selalu tekun berlatih, hal ini tergambar dari ekspresi bahagia mendapatkan sanjungan guru dan temanteman di kelas saat mampu menunjukkan keterampilan berbicara bahasa Indonesia dengan baik. Sebaliknya, Guru menerapkan pemberian punishment (hukuman) bagi yang tidak menggunakan bahasa Indonesia selama pembelajaran. Hukuman yang diberikan tidaklah dalam bentuk kekerasan fisik atau memberikan tugas tambahan yang dapat membebani siswa, Guru hanya meminta siswa untuk melakukan sesuatu yang mampu meningkatkan keterampilan berbicara bahasa Indonesia, 
seperti meminta siswa menceritakan sebuah tema cerita yang disepakati bersama secara singkat dengan menggunakan bahasa Indonesia yang baik dan benar, jika tetap ditemukan kekeliruan harus diulang hingga sempurna. Penggunaan Bahasa Indonesia saat pembelajaran di Kelas dilakukan secara berkesinambungan mampu memberikan perubahan dan meningkatkan keterampilan berbicara Bahasa Indonesia khsusunya saat berada di dalam kelas. Belum optimalnya penggunaan bahasa Indonesia disebabkan oleh kebiasaan berbahasa Daerah di luar jam pelajaran maupun saat berada di rumah maupun lingkungannya.

\section{SIMPULAN}

Pelaksanaan pembelajaran pada mata pelajaran Bahasa Indonesia di Kelas 7 Madrasah Tsanawiyah Negeri (MTsN 2) Sambas mengalami sejumlah problematika. Guru melaksanakan pembelajaran Bahasa Indonesia dalam kondisi siswa yang terbiasa menggunakan Bahasa Melayu Sambas, sedangkan Guru berasal dari daerah lain dan baru pertama kali mengajar di wilayah Kabupaten Sambas. Pelaksanaan pembelajaran mengalami hambatan saat Guru berbicara menggunakan Indonesia tetapi siswa meresponnya dengan Bahasa Melayu Sambas. Siswa memilih untuk menggunakan Bahasa Melayu Pontianak daripada berbahasa Indonesia jika menyadari bahwa Guru tidak memahami maksud ucapannya, tak jarang Guru mengambil inisiatif bertanya maupun meminta siswa mengulang pernyataannya jika dirasa belum dapat dipahami.

Secara umum keterampilan siswa membaca naskah berbahasa Indonesia di sekolah tersebut terbilang baik, namun keterampilan menulis dan berbicara menggunakan Bahasa Indonesia masih kurang memuaskan sehingga menyulitkan Guru dalam melaksanakan pembelajaran Bahasa Indonesia secara ideal berdasarkan tujuan pembelajaran yang hendak dicapai. Upaya membudayakan Bahasa Indonesia secara konsisten dilakukan Guru khususnya saat pembelajaran di Kelas, Guru memberikan motivasi dengan menyediakan reward (penghargaan) terhadap siswa yang menggunakan Bahasa Indonesia dengan baik dan punishment (hukuman) terhadap siswa yang melanggar. Namun, hukuman dimaksud yakni meminta siswa bercerita menggunakan Bahasa Indonesia dengan baik dan benar. Strategi tersebut mulai memberikan perubahan positif dalam membiasakan diri berbahasa Indonesia di dalam Kelas.

\section{REFERENSI}

Damayanti, Wahyu. (2016). Bentuk Derivasi Bahasa Melayu Dialek Sambas. Kandai. 12 (2), 255268

Emzir. (2018). Metodologi Penelitian Kualitatif; Analisis Data. Depok: Rajawali Pers 
Firdaus, Ananda Muhammad. (2019). Kemampuan Membaca Baik Siswa Indonesia 6 Persen (https://www.ayotasik.com/read/2019/09/03/3125/kemampuan-membaca-baik-siswaindonesia-6-persen). Diakses 8 Mei 2020

Hernawati, Heni. (2017). Penggunaan Bahasa Ibu Sebagai Pengantar Dalam Pembelajaran Bahasa. Jurnal Semantik. 6 (2), 83-91

Hikmat, Ade dan Nani Sholihati. (2013). Bahasa Indonesia Untuk Mahasiswa S1 dan Pasca Sarjana, Guru, Dosen, Praktisi dan Umum. Jakarta: Grasindo

Hamalik, Oemar. (2014). Kurikulum dan Pembelajaran cet 14. Jakarta: Bumi Aksara

Johan, Gio Mohamad. (2018). Analisis Kesalahan Berbahasa Indonesia Dalam Proses Diskusi Siswa Sekolah Dasar. Jurnal Pendidikan Bahasa dan Sastra. 18 (1), 136-149.

Lidwianan dan Izhar (2015). Bahasa Ibu Dalam Pembelajaran Anak Di Sekolah. Jurnal Pesona; STKIP Muhammadiyah Pringsewu Lampung. 1 (1)

Oktaviani A, Anisya. (2019). Analisis Hasil Uji Kemahiran Berbahasa Indonesia; Hasil Uji Pada Guru Tahun 2016-2018. Jakarta: Pusat Data dan Statistik Pendidikan dan Kebudayaan; Kemendikbud RI

Rahman, Astuti. (2016). Pengaruh Bahasa Daerah Terhadap Hasil Belajar Bahasa Indonesia Peserta Didik Kelas 1 SD Inpres Maki Kecamatan Lamba-Leda Kabupaten Manggarai Timur. Auladuna: Jurnal Pendidikan Dasar Islam. 3 (2), 71-79.

Samiudin. (2017). Pentingnya Memahami Perkembangan Anak Untuk Menyesuaikan Cara mengajar Yang Diberikan. Pancawahana: Jurnal Studi Islam. 12 (1), 1-9.

Sudaryono. (2018). Metodologi Penelitian. Depok: Rajawali Pers

Tarigan, D dan Lilis Sulistyaningsih. (1998). Analisis Kesalahan berbahasa. Jakarta: Direktorat Jenderal Pendidikan dan Menengah Kemendikbud RI

Wiyanto, Asul (2009). Terampil Menulis Paragraf. Jakarta: Grasindo

Winanto H, Dwi dkk. (2019). Statistik Kebahasaan 2019. Jakarta: Pusat Data dan Statistik Pendidikan dan Kebudayaan; Kemendikbud RI 
Wulandari, Arya dan Kadek R.P. (2016). Budaya dan Implikasinya Terhadap Pembelajaran Matematika Yang Kreatif. Jurnal Santiaji Pendidikan. 6 (1), 1-7.

Zein, Muh. (2016). Peran Guru Dalam Pengembangan Pembelajaran. Inspiratif Pendidikan. 5 (2), 274-285. 